\title{
Effect of gamma-mangostin on testosterone levels in Leydig cell culture of Sprague-Dawley rat induced by advanced glycation end products: a preliminary study
}

Dicky Moch Rizal ${ }^{1 *}$, Aditya Rifai Fauzi ${ }^{2}$ and Rustamaji ${ }^{3}$

From 3rd International Symposium on Congenital Anomaly and Developmental Biology 2019

Yogyakarta, Indonesia. 8-9 August 2019

\begin{abstract}
Background: Advanced glycation end products (AGE) is a toxic compound in the human body that can deteriorate health and induce an inflammatory response. One of the type of cells affected is Leydig cells, cells that produce testosterone and located in interstitial areas of the testes. Pericarp extract of Garcinia mangostana contains an antioxidant compound called gamma-mangostin that can decrease inflammatory responses and toxic effects of AGE. We aimed to compare the testosterone levels in Leydig cell culture of Sprague-Dawley rat induced by AGE only and following gamma-mangostin.

Methods: An experimental laboratory study was conducted on testosterone level in Leydig cell culture of SpragueDawley rats induced by advanced glycation end products $200 \mu \mathrm{g} / \mathrm{mL}$ and given gamma-mangostin $5 \mu \mathrm{M}$ compared to cell cultures that were not given gamma-mangostin.

Results: Nine Leydig cell cultures were ascertained and divided into three groups. No significant difference was found in the testosterone level of Leydig cell culture given AGE only $\left(1.33 \mathrm{ng} / 10^{5}\right.$ cells $\left./ 24 \mathrm{~h}\right)$ compared to the group given AGE and gamma-mangostin $\left(1.30 \mathrm{ng} / 10^{5}\right.$ cells/24 h) $(p=0.535)$.

Conclusion: The testosterone level in Leydig cell cultures induced by AGE were lower than those not given, but similar in the AGE-only group and group given gamma-mangostin. The mean testosterone levels in all groups were in the range of expected levels $\left(0.025-15 \mathrm{ng} / 10^{5}\right.$ cells $\left./ 24 \mathrm{~h}\right)$. Further study with larger samples is important to clarify and confirm our findings.
\end{abstract}

Keywords: Testosterone level, Leydig cell culture, Sprague-Dawley rat, Advanced glycation end products, Gammamangostin

\footnotetext{
* Correspondence: drdickyandrologi@ugm.ac.id

1 Department of Physiology, Faculty of Medicine, Public Health and Nursing

Universitas Gadjah Mada/Dr. Sardjito Hospital, Yogyakarta 55281, Indonesia

Full list of author information is available at the end of the article
}

(c) The Author(s). 2019 Open Access This article is distributed under the terms of the Creative Commons Attribution 4.0 International License (http://creativecommons.org/licenses/by/4.0/), which permits unrestricted use, distribution, and reproduction in any medium, provided you give appropriate credit to the original author(s) and the source, provide a link to the Creative Commons license, and indicate if changes were made. The Creative Commons Public Domain Dedication waiver (http://creativecommons.org/publicdomain/zero/1.0/) applies to the data made available in this article, unless otherwise stated. 


\section{Background}

The hormone testosterone is an essential part of men's health. Testosterone has a major function in the process of spermatogenesis and the formation of male secondary sexual characteristics, but many other functions are equally important, such as helping increase bone and muscle mass, inhibiting ageing, preventing cardiac arrhythmias, increasing fat metabolism, and preventing atherosclerosis. Testosterone is produced by Leydig cells, which are cells located in the interstitial testes, between seminiferous tubules. However, recently there has been an increase in the prevalence of hypogonadism in the elderly population, which occurs in as much as $20 \%$ in men aged $60-70$ years and $50 \%$ at the age of more than 80 years $[1,2]$. The World Health Organization (WHO) states that one in four couples in developing countries experience infertility and sexual dysfunction [3].

Several studies show that male reproductive health problems are the most common cause of couples with infertility cases. In Indonesia, there are $12 \%$ or about 3 million infertile couples. It is known that $30 \%$ of all cases of infertile couples are caused by men and tend to increase with older couples to $40 \%$ [4].

Infertility in men can be caused by a variety of factors, including infection, tumors, hormonal imbalances, smoking and obesity [5]. The most common cause is oxidative stress caused by an increase in Reactive Oxygen Species (ROS) in the testes and a decrease in antioxidant agents that disrupt the process of spermatogenesis [6]. Oxidative stress can significantly interfere with sperm function, which is an early sign of infertility in men [7].

One of the compounds that can cause the formation of ROS is Advanced Glycation End products (AGE). AGE is a toxic compound derived from proteins or lipids that undergo the process of glycation after binding to sugars. AGE can trigger damage to blood vessel walls, cardiovascular disease, neurodegenerative disorders, cancer and nonalcoholic steatohepatitis through inflammatory mechanisms $[8,9]$.

Mangosteen, which has the Latin name Garcinia mangostana, has long been used as a medicine to treat skin infections, wounds and diarrhea in Southeast Asia because it contains anti-inflammatory compounds. In one study, it was found that the mangosteen pericarp contained gamma-mangostin, a derivative of xanthones which can reduce the inflammatory reaction by reducing the expenditure of prostaglandin E2 [10]. The use of mangosteen pericarp extract containing gammamangostin is already familiar in Indonesia because it is known to have many health benefits. Beginning with increasing cases of infertility caused by a decrease in testosterone hormone, the authors are interested in examining testosterone levels in Leydig cell cultures of
Sprague-Dawley rats induced by AGE $200 \mu \mathrm{g} / \mathrm{mL}$ and given gamma-mangostin $5 \mu \mathrm{M}$.

\section{Methods \\ Samples}

This study was conducted from April 2014-May 2015 at Cell culture laboratory, Department of Physiology, Faculty of Medicine, Public Health and Nursing, Universitas Gadjah Mada, Yogyakarta, Indonesia. An in vitro experimental laboratory study was conducted with samples of male Sprague-Dawley rats aged 90 days, weighing around 300-350 g.

This study was approved by the Institutional Review Board of the Faculty of Medicine, Public Health and Nursing, Universitas Gadjah Mada, Yogyakarta, Indonesia (KE/FK/342/EC/2015).

\section{Testis retrieval}

We used animal handling guidelines, the common surgical procedures in rodents from Foley [11]. The rats were fasted for about $10 \mathrm{~h}$ before removing the testicles. Then, the rats were anaesthetized using ketamine $\mathrm{HCl} 0.3 \mathrm{~mL} /$ $100 \mathrm{grBW}$ intramuscularly. After being unconscious, the four limbs of the rat were fixed using a rope on the operating table. Hairs in the abdomen and testicles were moistened using wet cotton and then shaved until the skin appears as limited as the area to be opened. The area to be opened was sterilized with an alcohol swab and then incised about $2 \mathrm{~cm}$ along the midline of the abdomen with a scalpel. A peritoneal incision of $1.5-2 \mathrm{~cm}$ long was made. Using a pair of curved tweezers and small scissors, a skin incision was made midline along the lower abdomen about $0.5 \mathrm{in}$. anterior to the genitals, and about $1.0 \mathrm{~cm}$ long. The skin was opened towards the right and left to remove each of the testicles from just one incision. Two vas deferens were then identified on the side of the testis. The left vas deferens was gently grasped with the forceps and then partially lifted so that the incision was clearly visible (Fig. 1).

The vas deferens was then ligated and cut as described above. After the testis was taken, the wound area was cleaned and observed for any bleeding. The peritoneum and the skin were re-sewn with absorbable threads. Next, the stitches were smeared with povidone-iodine and allowed to dry. Finally, the rats were euthanized by administering lethal dose of ketamin $0.45 \mathrm{mg} / \mathrm{kg}$.

\section{Making AGE-BSA preparations}

AGE-BSA is AGE derived from Bovine Serum Albumin (BSA), which is reacted with glucose and incubation for several weeks. The AGE-BSA used in this study is the initial preparation of powder, which was then dissolved using phosphate-buffered saline (PBS). The AGE-BSA used in this study is a Biovision product with catalogue 


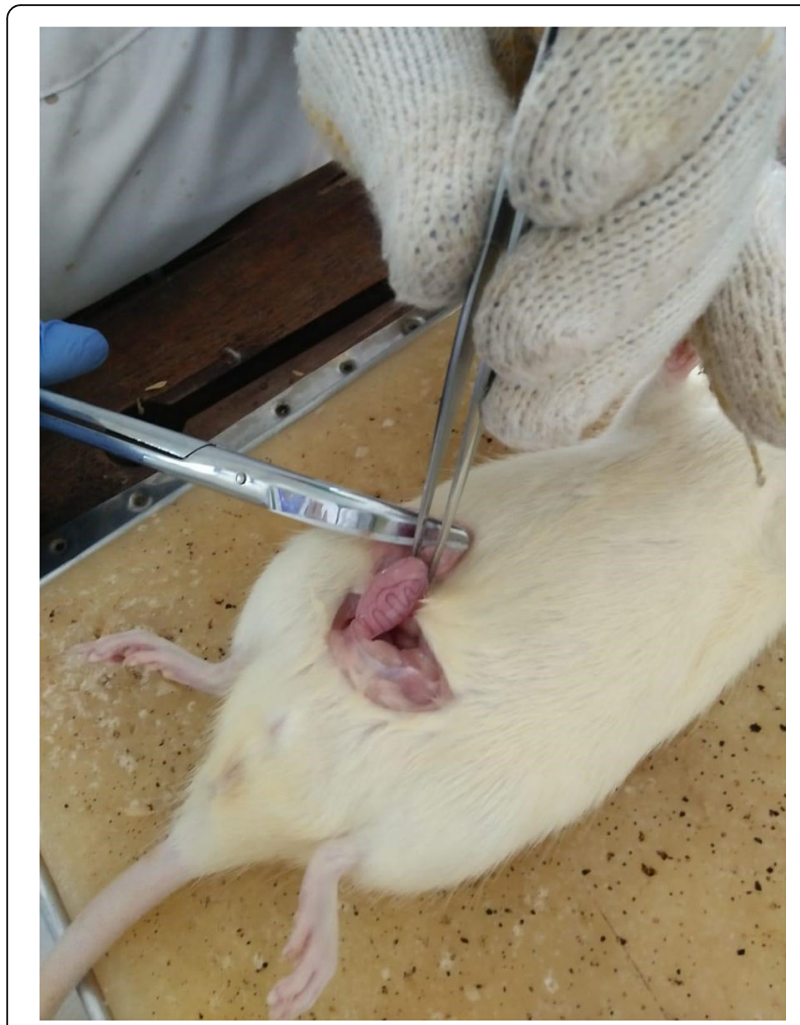

Fig. 1 Testes retrival from Sprague-Dawley rat

number 2221-10 and has a specificity of 98\%. This product shows an AGE content of $7000 \%$ compared to ordinary BSA.

\section{Leydig cell isolation and culture}

In this procedure, we used guidelines from the previous study by Sun et al. [12]. Epididymis, visible blood vessels, fat and other connective tissue are removed carefully from the testes with microscissors. The tunica albuginea was then dissected out, and a pair of testicles from each rat were incubated into a $50 \mathrm{ml}$ centrifuge tube. Testes were then placed in a mixture of previously cooled Dulbecco's modified Eagle medium (DMEM)/Ham's F12 Media (Sigma-Aldrich, Merck KGaA, Darmstadt, Germany) 1:1, then they were mixed with $15 \mathrm{mM}$ NaHCO3, $20 \mathrm{mM}$ HEPES, pH 7.4; $100 \mathrm{U} / \mathrm{ml}$ penicillin, $2.5 \mathrm{pg} / \mathrm{ml}$ amphotericin $\mathrm{B}$ and $0.1 \% \mathrm{BSA}$, with temperature continuously maintained in the laboratory with ice. All solutions were sterile, and all procedures done in sterile conditions.

Testicular tissue pieces were isolated for the process of isolating Leydig cells and placed in fresh medium, and then tunica albuginea was removed. The tissue was then rinsed three times with the media and finely chopped in a petri dish.

Tissue fragments were placed in a solution of $0.04 \%$ collagenase (type I, Sigma Chemical Co., $130 \mathrm{U} / \mathrm{mg}$ ) and
$1.0 \mu \mathrm{g} / \mathrm{ml}$ trypsin inhibitors in the culture media mentioned above, under constant agitation at $34{ }^{\circ} \mathrm{C}$ for 40 $\min$.

After this procedure, the collagenase solution was diluted four times with a culture medium, and a small piece of tissue was inserted for sedimentation for 10 min. The supernatant was centrifuged at room temperature for $3 \mathrm{~min}$ at $200 \mathrm{~g}$, and the cell pellets were washed twice and then stored in fresh tissue culture media. Administration of both suspension for $30 \mathrm{~min}$ with the same conditions was done on the remaining tissue pieces. Cells were collected and washed as described in the procedure above.

The suspension obtained from the two collagenase treatments was combined, and the sedimentation produced from the 10 and 30-min treatments were taken to eliminate the remaining tubular segments. Initial cells were obtained from the supernatant from the use of 4layer percoll gradients $(21,26,34$ and $60 \%)$. The gradient was centrifuged at $800 \mathrm{~g}$ for $30 \mathrm{~min}$ at room temperature. The layers formed between 40 and $60 \%$ concentrations were taken (Fig. 2) and washed with a medium to remove the Percoll medium. Viability was confirmed by a separate, more than $90 \%$ Tryptan Blue test.

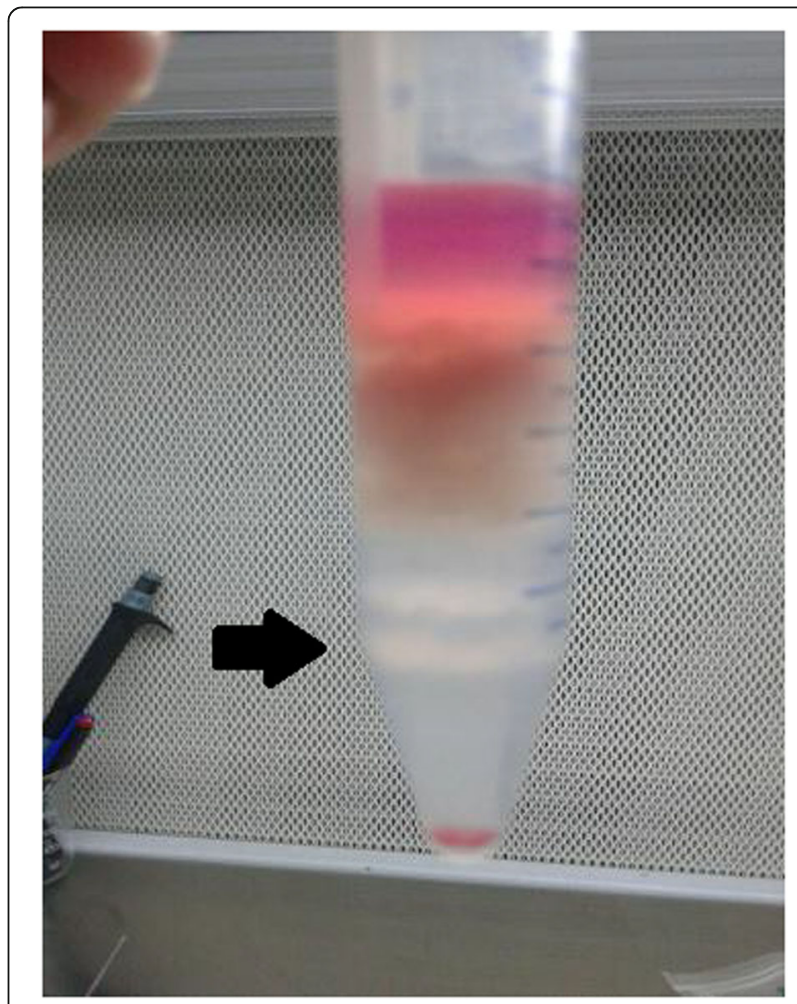

Fig. 2 After the final centrifugation process, Leydig cells will form a ring-like layer between 40 and $60 \%$ gradient medium concentration. The black arrow indicates the Leydig cell-rich layer 
Approximately $2 \times 10^{5} / \mathrm{cm}^{2}$ cells were planted in the well in the DMEM/Ham's F12 media, and then were added $15 \mathrm{mM} \mathrm{NaHCO}$, $20 \mathrm{mM}$ HEPES, pH 7.4; $100 \mathrm{U} /$ $\mathrm{mI}$ penicillin, $2.5 \mathrm{pg} / \mathrm{ml}$ amphotericin $\mathrm{B}, 10 \mu \mathrm{g} / \mathrm{ml}$ transferrin; $5 \mu \mathrm{g} / \mathrm{ml}$ hydrocortisone and $2 \%$ Fetal Bovine Serum (Sigma-Aldrich, Merck KGaA, Darmstadt, Germany). Culture is conducted in an incubator which was regulated at $34{ }^{\circ} \mathrm{C}$ with a pressure of $5 \% \mathrm{CO}_{2}$ in the air. Cells were estimated to coagulate in the media $24 \mathrm{~h}$ after culture. In the initial period, the cells will stick together in the first hours of culture and begin to grow, then began to close to confluence in 7 days (Fig. 3).

\section{Testosterone levels measurement}

Testosterone concentration in the media was examined by ELISA according to the procedure. The fluid to be examined was dripped with $20 \mu \mathrm{L}$ of standard fluid (biotinylated polyclonal antibody) and then drops of $200 \mu \mathrm{L}$ of the conjugate enzyme were added and $100 \mu \mathrm{L}$ of the testosterone derivative labelled with the ruthenium complex. The microparticles in the mixture were captured by electrodes, which then induced chemiluminescent emissions, and the results were calculated with the photomultiplier recorded in ng/ $10^{5}$ cells $/ 24 \mathrm{~h}$. The measurement validity was $0.025-15 \mathrm{ng} / 10^{5}$ cells $/ 24 \mathrm{~h}$ (Roche).

\section{Preparation of gamma-mangostin}

Gamma-mangostin is a xanthone derivative derived from mangosteen pericarp extract (Garcinia mangostana). Gamma mangostin used in this study is a product from Sigma-Aldrich with MG 6824 catalogue numbers in powder preparations which are then dissolved with dimethyl-sulfoxide (DMSO) to obtain a concentration of $20 \mathrm{mM}$ as a solution and then diluted as needed. Gamma-mangostin has a purity level of $98 \%$.

\section{Statistical analysis}

All data were recorded in a computer database and analyzed using the SPSS Statistics 22 program (SPSS Inc., Chicago, IL, USA). The results are displayed as mean values \pm standard deviation (SD). Mean differences between groups were analyzed using one-way ANOVA test. Post-hoc analysis was performed using the LSD method to determine the groups that had mean differences. A $p$-value $<0.05$ was considered statistically significant.

\section{Results}

Association between gamma-mangostin, AGE, and testosterone level

Table 1 shows that the average testosterone level is higher in group 2 (Leydig cell + AGE-BSA cell culture $200 \mu \mathrm{g} / \mathrm{mL}$ ) than group 3 (Leydig cell + AGE-BSA cell culture $200 \mu \mathrm{g} / \mathrm{mL}$ + gamma-mangostin $5 \mu \mathrm{M}$ ) and the highest at group 1 (control) with a significant difference $(p=0.036)$.

After a post-hoc analysis with the LSD test, significant differences $(p<0.05)$ were found in the comparison of the group 1 (control) group with group 2 (AGE-BSA $200 \mu \mathrm{g} / \mathrm{mL}$ group) and group 1 (control) with the group 3 (AGE-BSA group $200 \mu \mathrm{g} / \mathrm{mL}+$ gamma-mangostin $5 \mu \mathrm{M})$.

Linearity test was done on testosterone level data, showing a significance value of 0.297 , which means there is a significant linear relationship between the dependent variables (testosterone levels) and independent variables (AGE-BSA and gamma-mangostin). Linearity graphic shown in Fig. 4.

\section{Discussion}

Based on the results of the research conducted, induction of AGE $200 \mu \mathrm{g} / \mathrm{mL}$ in Leydig cell culture in Sprague-Dawley rat showed that the lowest average testosterone level was in group $3\left(1.30 \mathrm{ng} / 10^{5}\right.$ cells $\left./ 24 \mathrm{~h}\right)$ and the highest in group $1\left(1.47 \mathrm{ng} / 10^{5}\right.$ cells $\left./ 24 \mathrm{~h}\right)$ with a significant difference $(p=0.036)$. This significant difference means that intergroup testosterone levels are relatively different. Based on post-hoc analysis with LSD test, the results showed that the main differences were

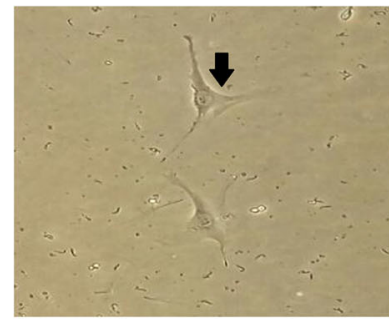

A

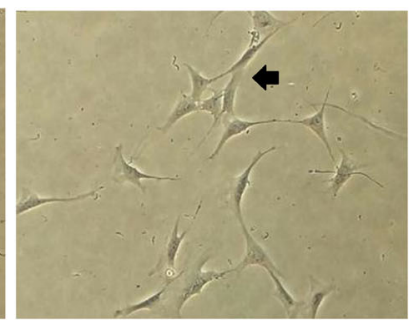

B

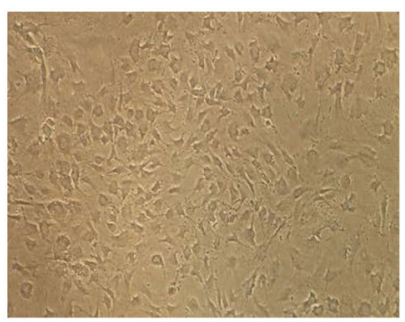

C

Fig. 3 Leydig cell culture at days 2, 4 and 7. Black arrows indicate Leydig cells. a. The appearance of Leydig cells in culture 24-48 h: Leydig cells are still less. Leydig cells that have grown in polygonal form, $\mathbf{b}$. The appearance of Leydig cells in culture in $96 \mathrm{~h}$. Leydig cells are increasing in number. c Leydig cell appearance in $156 \mathrm{~h}$. Leydig cells have proliferated rapidly and reached confluent of about $80 \%$. Culture was observed using an inverted microscope at 100x magnification 
Table 1 Testosrerone level mean values

\begin{tabular}{lllcr}
\hline Variable & $\begin{array}{l}\text { Group 1 } \\
\text { Control } \\
(n=3)\end{array}$ & $\begin{array}{l}\text { Group 2 } \\
\text { AGE-BSA 200 } \mu \mathrm{g} / \mathrm{mL} \\
(n=3)\end{array}$ & $\begin{array}{l}\text { Group 3 } \\
\text { AGE-BSA 200 } \mu \mathrm{g} / \mathrm{mL}+\text { gamma-mangostin 5 } \mu \mathrm{M}(n=3)\end{array}$ \\
\hline Testosterone levels $\left(\mathrm{ng} / 10^{5}\right.$ cells/24h) & $1.47 \pm 0.05$ & $1.33 \pm 0.03$ & $1.30 \pm 0.10$ & $0.036^{*}$
\end{tabular}

Data were served in mean \pm SD

${ }^{*}, p<0.05$ is considered statistically significant. AGE-BSA Advanced glycation end products-Bovine Serum Albumin

between group 1 and group $2(p=0.039)$ and group 1 with group 3 ( $p=0.016)$.

From the results obtained, it can be seen that the decrease in testosterone levels in group 3 is not significant when compared to group 2. This finding shows that gamma-mangostin can inhibit the oxidation process caused by AGE according to the theoretical basis so that Leydig cell cultures can still produce testosterone accordingly at an expected level. In a study conducted by Jung [12], it was found that the mangostin compound had an antioxidant effect on rat breast preneoplastic lesions at IC50 $2.44 \mu \mathrm{M}$, while in this study gammamangostin levels were used at $5 \mu \mathrm{M}$.

Murugesan [13] conducted a study of Leydig cell culture induced by polychlorinated biphenyl (PCB) and was given vitamins $C$ and $E$. In this study it was found that there was a decrease in testosterone production in vitro due to a decrease in steroidogenic enzyme activity and the number of luteinizing hormone (LH) receptors caused by PCBs in conditions basal and LH stimulated. There was also an increase in ROS and lipid peroxidation, as well as a decrease in intracellular antioxidant enzymes. Provision of vitamin $C$ and $E$ simultaneously has

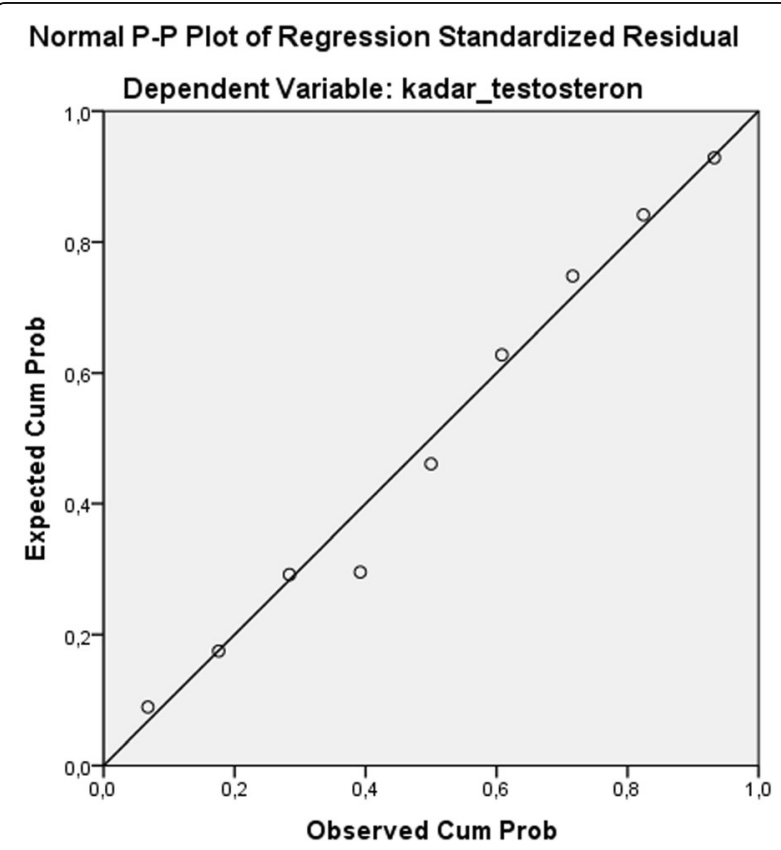

Fig. 4 Linearity graphic of testosterone level been shown to reduce ROS and lipid peroxidation, which is supported by normal steroidogenic activity and antioxidant enzymes.

In a study conducted by Al-Olayan [14] regarding the effect of Pomegranate (Punica granatum) on testes of rats given carbon tetrachloride poisons, a significant increase in testosterone, antioxidant enzyme activity, and decreased lipid peroxidation after Pomegranate administration were found. The same results were also found in a study conducted by Chang [15] regarding the cytoprotective effect of Morinda officinalis on Leydig cells induced by hydrogen peroxide, showing an increase in antioxidant activity and an increase in testosterone production under oxidative stress conditions in Leydig cell culture in TM3 rats.

The decrease in testosterone levels in group 3 may also be caused by gamma-mangostin that can inhibit cell growth through the mechanism of intracellular ROS production and mitochondrial dysfunction as in the study conducted by Chang and Yang [16] in colorectal adenocarcinoma cells. Wang [17] mentioned in his study that gamma-mangostin with a level of $5 \mu \mathrm{g} / \mathrm{mL}$ could induce apoptosis and inhibit the G1 phase cell cycle in melanoma cells that were given behavior for $48 \mathrm{~h}$. In another study, it was found that gamma-mangostin had an antiproliferative effect on human colon cancer cells DLD-1 at a level of $20 \mu \mathrm{M}$ and incubated for $72 \mathrm{~h}$ through the $\mathrm{S}$ phase inhibition mechanism in the cell cycle [18].

In normal metabolism, Leydig cells produce ROS through an electron transport chain mechanism, and when steroid hydroxylation occurs by the cytochrome P450scc enzyme [13]. Jen [19] stated that ROS and activation of the mitochondrial apoptotic pathway could induce apoptotic initiator caspase-9, then caspase-9 would activate its effector, caspase-3. Kim [20] mentioned in his study that caspase-3 activation in Leydig cells led to Leydig cell apoptosis. Caspase-3 may play a role in the activation of core proteins that accelerate the final process of apoptosis, namely DNA fragmentation, which causes a gradual decrease in steroidogenesis activity by Leydig cells, as evidenced by the coloring of $3 \beta-H S D$ [20].

The experiments conducted by Shakui et al. [16], in prostate cancer cells given hydroxanthone compounds extracted from the roots of the Garcinia subelliptica 
plant found an antiandrogenic effect on these cells. The chemical structure of the benzopyrene ring found in most xanthone compounds is capable of mediating the inhibitory process of the Sp- 1 transcription factor found in the androgen receptor promoter (AR) and modifying posttranscriptional AR protein [21].

Another possibility that can cause no increase in testosterone levels in Leydig cell cultures is the low or lack of gamma-mangostin levels given. Nakatani [18] stated in his study that gamma-mangostin effectively inhibited the inflammatory process of C6 mouse glioma cells at a level of $10 \mu \mathrm{M}$. In this study, the gamma-mangostin levels used were $5 \mu \mathrm{M}$.

However, the small sample size in this study and only a single concentration of gamma-mangostin was given to the cell cultures are our main study limitations. Further study is necessary to investigate whether different concentrations of gamma-mangostin would decrease the toxic effect of AGE and increase testosterone levels. Finally, none of our findings showed that administration of gamma-mangostin could increase testosterone levels in Leydig cells culture of Sprague-Dawley rat induced by AGE.

\section{Conclusions}

In conclusion, testosterone levels in Leydig cell cultures induced by AGE were lower than the control group. Giving gamma-mangostin $5 \mu \mathrm{M}$ does not increase testosterone levels in Leydig cell cultures induced by AGE $200 \mu \mathrm{g} / \mathrm{mL}$. Furthermore, this is the first study to examine the effect of gamma-mangostin administration on testosterone level of AGE-induced Leydig cell cultures. Further study with larger samples and different gammamangostin concentrations is important to confirm and clarify our findings.

\section{Abbreviations \\ AGE: Advanced glycation end products; AR: Androgen receptor; BSA: Bovine serum albumin; DMSO: Dimethyl-sulfoxide; ELISA: Enzyme-linked immunosorbent assay; LH: Luteinizing hormone; PBS: Phosphate buffered saline; PCB: Polychlorinated biphenyl; ROS: Reactive oxygen species; SD: Standard deviation; WHO: World Health Organization}

\section{Acknowledgements}

We are thankful to all those who offered excellent technical help during the study. Some results for the manuscript are from Aditya Rifqi Fauzi's thesis.

\section{Consent to publication}

Not applicable.

\section{About this supplement}

This article has been published as part of BMC Proceedings Volume 13 Supplement 11, 2019: Selected articles from the 3rd International Symposium on Congenital Anomaly and Developmental Biology 2019 (ISCADB 2019). The full contents of the supplement are available online at https://bmcproc. biomedcentral.com/articles/supplements/volume-13-supplement-11.

\section{Authors' contributions}

DMR conceived the study. ARF drafted the manuscript, R critically revised the manuscript for important intellectual content. DMR, ARF and R facilitated all project-related tasks. All authors read and approved the final manuscript.

\section{Funding}

Publication costs are funded by Faculty of Medicine, Public Health and Nursing, Universitas Gadjah Mada.

\section{Availability of data and materials}

All data generated or analyzed during this study are included in the submission. The raw data are available from the corresponding author on reasonable request.

Ethics approval and consent to participate

The Institutional Review Board of Faculty of Medicine, Public Health and Nursing, Universitas Gadjah Mada/Dr. Sardjito Hospital approved this study (KE/FK/342/EC/2015).

\section{Competing interests}

The authors declare that they have no competing interests.

\section{Author details}

${ }^{1}$ Department of Physiology, Faculty of Medicine, Public Health and Nursing Universitas Gadjah Mada/Dr. Sardjito Hospital, Yogyakarta 55281, Indonesia. ${ }^{2}$ Faculty of Medicine, Public Health and Nursing, Universitas Gadjah Mada/Dr. Sardjito Hospital, Yogyakarta 55281, Indonesia. ${ }^{3}$ Department of Pharmacology and Therapy, Faculty of Medicine, Public Health and Nursing Universitas Gadjah Mada, /Dr. Sardjito Hospital, Yogyakarta 55281, Indonesia.

Published: 16 December 2019

\section{References}

1. Guyton AC, Hall JE. Textbook of medical physiology. 11th ed. Philadelphia: Elsevier; 2006

2. Herring MJ, Oskui PM, Hale SL, Kloner RA. Testosterone and the cardiovascular system: a comprehensive review of the basic science literature. J Am Heart Assoc. 2013;2:e000271.

3. Tanikawa T, Okada Y, Tanikawa R, Tanaka Y. Advanced glycation end products induce calcification of vascular smooth muscle cells through RAGE/p38 MAPK. J Vasc Res. 2009:46:572-80.

4. Irvine DS. Epidemiology and aetiology of male infertility. Hum Reprod. 1998; 13(suppl 1):33-44.

5. Mayo Clinic 2014, Infertility: Causes (Citation), Accessed 4 June 2015, < http:/www.mayoclinic.org/diseases-conditions/infertility/basics/causes/ con-20034770>.

6. Murugesan P, Balaganesh M, Balasubramanian K, Arunakaran J. Effects of polychlorinated biphenyl (Aroclor 1254) on steroidogenesis and antioxidant system in cultured adult rat Leydig cells. J Endocrinol. 2007;192:325-38.

7. Shakui T, Iguchi K, Ito T, Baba M, Usui S, Oyama M, Tosa H, linuma M, Hirano K. Anti-androgenic activity of hydroxyxanthones in prostate cancer LNCaP cells. Fitoterapia. 2014;92:9-15.

8. Basta G, Schmidt AM, De Caterina R. Advanced glycation end products and vascular inflammation: implications for accelerated atherosclerosis in diabetes. Cardiovasc Res. 2004;63:582-92.

9. Singh R, Barden A, Mori T, Beilin L. Advanced glycation end-products: a review. Diabetologia. 2001;44:129-46.

10. Midzak AS, Chen H, Papadopoulos V, Zirkin BR. Leydig cell aging and the mechanisms of reduced testosterone synthesis. Mol Cell Endocrinol. 2009; 299:23-31.

11. Foley PL. Laboratory Animal Medicine and Management. Ithaca NY: Office of Animal Research Education and Compliance, University of Virginia, Charlottesville, VA, USA: International Veterinary Information Service; 2005. (www.ivis.org). Common surgical procedures in rodents

12. Sun J, Zhong L, Zhu Y, Liu G. Research on the isolation of mouse Leydig cells using differential digestion with a low concentration of collagenase. $J$ Reprod Dev. 2011;57(3):433-6.

13. Jung HA, Su BN, Keller WJ, Mehta RG, Kinghorn AD. Antioxidant xanthones from the pericarp of Garcinia mangostana (Mangosteen). J Agric Food Chem. 2006;54:2077-82. 
14. Merhi Z. Advanced glycation end products and their relevance in female reproduction. Hum Reprod. 2013;29:135-45.

15. Al-Olayan EM, El-Khadragy MF, Metwally DM, Moneim AE. Protective effects of pomegranate (Punica granatum) juice on testes against carbon tetrachloride intoxication in rats. BMC Complement Altern Med. 2014;14:164.

16. Chang MS, Kim WN, Yang WM, Kim HY, Oh JH, Park SK. Cytoprotective effects of Morinda officinalis against hydrogen peroxide-induced oxidative stress in Leydig TM3 cells. Asian J Androl. 2008;10:667-74.

17. Chang HF, Yang LL. Gamma-mangostin, a micronutrient of mangosteen fruit, induces apoptosis in human colon cancer cells. Molecules. 2012;17: 8010-21.

18. Tahara N, Imaizumi T, Takeuchi M, Yamagishi SI. Insulin resistance is an independent correlate of high serum levels of advanced glycation end products (AGEs) and low testosterone in non-diabetic men. Oxidative Med Cell Longev. 2010;3:262-5.

19. Nakatani K, Yamakuni T, Kondo N, Arakawa T, Oosawa K, Shimura S, Inoue H,

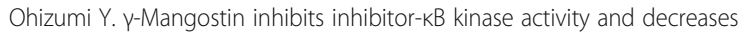
lipopolysaccharide-induced cyclooxygenase-2 gene expression in C6 rat glioma cells. Mol Pharmacol. 2004;66:667-74.

20. Jen CY, Lin CY, Huang BM, Leu SF. Cordycepin induced MA-10 mouse Leydig tumor cell apoptosis through caspase-9 pathway. Evid Based Complement Alternat Med. 2011;2011:1.

21. Pedraza-Chaverri J, Cárdenas-Rodríguez N, Orozco-lbarra M, Pérez-Rojas JM. Medicinal properties of mangosteen (Garcinia mangostana). Food Chem Toxicol. 2008;46:3227-39.

\section{Publisher's Note}

Springer Nature remains neutral with regard to jurisdictional claims in published maps and institutional affiliations.

Ready to submit your research? Choose BMC and benefit from:

- fast, convenient online submission

- thorough peer review by experienced researchers in your field

- rapid publication on acceptance

- support for research data, including large and complex data types

- gold Open Access which fosters wider collaboration and increased citations

- maximum visibility for your research: over $100 \mathrm{M}$ website views per year

At $\mathrm{BMC}$, research is always in progress.

Learn more biomedcentral.com/submissions 